\title{
Meningkatkan Perencanaan Karir Melalui Layanan Informasi Dengan Teknik Biblio-Therapy Pada Siswa Kelas Xi IPS 2 Sma Negeri 1 Bengkayang
}

\author{
Hendrik \\ hen82hendrik@gmail.com \\ Rian Hidayat \\ Rianhidayat465@gmail.com
}

IKIP PGRI Pontianak

\begin{abstract}
Abstrak
Tujuan penelitian ini adalah1) mengetahui perencanaan karir siswa kelas XI IPS 2 Sekolah Menengah Atas Negeri 1 Bengkayang, 2) mengetahui Pelaksanaan layanan informasi dengan teknik Biblio-therapy untuk meningkatkan perencanaan karir siswa kelas XI IPS 2 Sekolah Menengah Atas Negeri 1 Bengkayang, 3) peningkatkan perencanaan karir siswa melalui layanan informasi dengan teknik Bibliotherapy kelas XI IPS 2 Sekolah Menengah Atas Negeri 1 Bengkayang. Metode penelitian yang digunakan dalam penlitian ini adalah metode Deskriptif sedangkan bentuknya yaitu penelitian tindakan bimbingan dan konseling (PTBK). Subjek penelitian yang digunakan yang berjumlah 34 siswa kelas XI IPS 2 Sekolah Menengah Atas Negeri 1 Bengkayang. Teknik pengumpulan data yang digunakan adalah teknik observasi langsung, teknik komunikasi langsung, teknik komunikasi tidak langsung, teknik studi dokumnter. Alat pengumpul data yang digunakan berupa panduan obesrvasi, panduan wawancara, skala psikologis, dokumentasi. Hasil pnlitian ini menunjukan bahwa meningkatkan perencanaan karir melalui layanan informasi dengan teknik Biblio-thrapy pada siswa kelas XI IPS 2 Sekolah Menengah Atas Negeri 1 Bengkayang. Meningkatkan perencanaan karir, melalui 4 langkah 1) perencanaan 2) pelaksanaan 3) pengamatan 4) refleksi. Berdasarkan Hasil penelitian terdapat peningkatan peresentase awal 51\% mengalami peningkatan setelah dilaksanakannya tindakan pada siklus I meningkat menjadi 64\% namun masih kategori "Cukup" dan setelah dilaksanakan tindakan pada siklus II meningkat menjadi $74 \%$ dengan kategori "Baik". Dari hasil peningkatan penelitian diatas disarankan guru bimbingan dan konseling dapat menggunakan layanan informasi dengan teknik biblio-therapy untuk meningkatkan perencanaan karir.
\end{abstract}

Kata Kunci: Perencanaan Karir, Layanan Informasi, Teknik Biblio-Therapy.

The objectives of this study were 1) knowing the career planning of students in class XI IPS 2 at Public Senior High School 1 Bengkayang, 2) knowing the implementation of information services using the Biblio-therapy technique to improve the career planning for students in class XI IPS 2 at SMA Negeri 1 Bengkayang Student career planning through information services with the Biblio-therapy technique class XI IPS 2 Senior High School 1 Bengkayang. The research method used in this study is the descriptive method while the form is guidance and counseling action research (PTBK). The research subjects used were 34 students of class XI IPS 2 at Public Senior High School 1 Bengkayang. The data collection techniques used were direct observation techniques, direct communication techniques, indirect communication techniques, and doctoral study techniques. Data collection tools used were observation guides, interview guides, psychological scales, documentation. The results of this study indicate that improving career planning through information services with the Biblio-thrapy technique for class XI IPS 2 students of SMA Negeri 1 Bengkayang. Improve career planning, through 4 steps 1) planning 2) implementation 3) observation 4) reflection. Based on the results of the study, there was an increase in the initial percentage of $51 \%$, an increase after the implementation of the action in cycle I increased to $64 \%$ but it was still in the "Enough" category and after the action was carried out in the second cycle it increased to $74 \%$ in the "Good" category. From the results of the increase in research above, it is suggested that guidance and counseling teachers can use information services with bibliotherapy techniques to improve career planning

Keywords: Career Planning, Information Services, Biblio-Therapy Techniques. 


\section{PENDAHULUAN}

Badan Pusat Statistik Kalimantan Barat pada tahun 2019 terdapat jumlah angka pengangguran pada kawasan Kalimantan Barat mencapai 387.43 jiwa. Dilihat dari kontribusi jumlah angka pengangguran pada lulusan Sekolah Menengah Atas (SMA) lebih tinggi dibandingkan lulusan pada jenjang lainnya dengan jumlah 8248 jiwa pada tahun 2018. Dengan besarnya angka pengangguran yang dihasilkan dari lulusan Sekolah Menengah Atas, hal tersebut diduga kurang optimalnya perencanaan karir siswa lulusan Sekolah Menengah Atas untuk memasuki dunia kerja.

Salah satu aspek yang berkembang dengan kemajuan teknologi yaitu jenis pekerjaan. Seiringan dengan hal tersebut siswa diharapan dapat mengoptimalkan potensi dan dituntut untuk memiliki skill agar dapat bersaing sesuai dengan tuntutan perkembangan zaman. Melihat fenomena tersebut, untuk menentukan karir yang sesuai dengan potensi yang dimiliki siswa perlu untuk direncanakan terlebih dahulu. Perencanaan karir merupakan salah satu aspek yang dianggap penting dalam perkembangan karir siswa. Semua itu tentunya tidak lepas dari pertimbangan terhadap berbagai faktor, baik itu faktor internal maupun eksternal. Faktor internal yaitu faktor yang berasal dari siswa itu sendiri yang meliputi bakat, minat, kepribadian dan potensi-potensi lainya. Sedangkan faktor eksternal yaitu faktor-faktor sosial, faktor yang berasal dari luar siswa seperti keluarga dan lingkungan masyarakat yang memegang peran penting dalam perkembangan siswa. Sehubungan dengan hal tersebut Suherman (2008:116) mengatakan: "Aspek perencanaan karir siswa terdiri dari aspek-aspek yaitu, mempelajari informasi karir, membicarakan karir dengan orang dewasa, mengetahui persyaratan pendidikan untuk karir yang dinginkan, serta dapat merencanakan apa yang harus dilakukan setelah tamat dari sekolah".

Kemampuan siswa dalam mempersiapkan karir masih terlihat sangat rendah, hal tersebut tampak dalam berbagai masalah baik yang berkaitan dengan pemilihan program studi lanjut, pemilihan rencana pekerjaan, sampai ketidaksiapan para siswa setelah lulus sekolah. Hal tersebut memberikan keprihatinan dunia pendidikan untuk meningkatkan kemampuan siswa dalam merencanakan karirnya terutama di Sekolah Menengah Atas.

Berdasarkan teori perkembangan Ginzberg (Winkel dan Sri Hastuti, 2013: 635) menyebutkan bahwa: "Siswa Sekolah Menengah Atas berada pada tahap tentative dimana siswa sudah mampu memikirkan atau merencanakan karir mereka berdasarkan minat, nilai atau potensi yang mereka miliki”. Akan tetapi hal itu bertolak belakang dengan masalah yang ditemukan dilapangan, siswa mengalami kebingungan dalam merencanakan karirnya, maka dari itu untuk meningkatkan perencanaan karir tentunya memerlukan informasi terkait dengan dunia kerja. Disekolah layanan informasi yang disampaikan oleh guru Bimbingan dan Konseling sebagai pelaksana program Bimbingan dan Konseling dapat membantu siswa dalam meningkatkan perencanaan karirnya.

Program Bimbingan dan Konseling di sekolah sangat berperan penting dalam membantu siswa untuk merencanakan karirnya. Pelaksanaan bimbingan dan konseling yang profesional saat ini di fokuskan pada generasi muda yang masih duduk dibangku sekolah. Prayitno (2012: 8) menyebutkan program Bimbingan dan Konseling terdiri dari 4 bidang, bimbingan pribadi, bimbingan sosial, bimbingan belajar, dan bimbingan karir, 9 layanan antara lain layanan orientasi, layanan informasi, layanan penempatan dan penyaluran, layanan pembelajaran, layanan konseling perorangan, layanan bimbingan kelompok, layanan konseling kelompok, serta 5 kegiatan pendukung antara lain instrumentasi Bimbingan dan Konseling, himpunan data, konfensi kasus, kunjungan rumah, dan alih tangan kasus. Hal tersebut sekiranya bisa berperan aktif dalam melaksanakan program Bimbingan dan Konseling untuk meningkatkan perencanaan karirnya.

Adapun layanan yang digunakan sebagai alternatif untuk menunjang proses kegiatan bimbingan dan konseling salah satunya adalah layanan informasi. Layanan informasi adalah layanan yang diberikan kepada siswa untuk menghindari masalah yang menghambat pencapaian perkembangan siswa baik itu perkembangan pribadi, sosial, belajar, dan karir dengan harapan siswa bisa mengambil pertimbangan dan keputusan untuk dirinya sendiri. W.S.Winkel (2013: 623) menyatakan bahwa: "Layanan informasi adalah layanan bimbingan 
dan konseling yang memungkinkan siswa menerima dan memahami berbagai informasi seperti informasi pendidikan dan informasi jabatan yang dapat digunakan sebagai bahan petimbangan dan pengambilan keputusan untuk kepentingan siswa".

Melalui layanan informasi siswa dapat memahami berbagai informasi baik itu informasi pendidikan maupun informasi jabatan atau karir yang dapat dijadikan sebagai bahan pertimbangan dalam pengambilan keputusan bagi siswa, khususnya dalam merencanakan karir. Setelah memberikan layanan informasi tentu agar lebih efektif dalam pemberian layanan maka diperlukan kreativitas dalam mengembangkan layanan yang diberikan kepada siswa dalam mengatasi permasalahaanya dan juga sangat memerlukan alat bantu dalam pengembangan materi nantinya, alat bantu yang disebut adalah teknik Bibliotherapy. Teknik ini sangat membantu untuk memfasilitasi siswa dalam merencanakan karirnya.

Teknik Biblio-therapy merupakan implementasi dari bidang bimbingan karir, akan membantu siswa dalam merencanakan karir di masa mendatang agar karir yang dipilih sesuai dengan bakat dan minatnya. Hal ini sejalan dengan pendapat Dewa Ketut Sukardi (2008:35) yang mengatakan"Bimbingan karir dalam setting kelompok juga dapat digunakan untuk membantu individu dalam memecahkan masalah karir atau pekerjaan untuk memperoleh penyesuaian diri sebaik-baiknya di masa depan". Teknik Biblio-therapy digunakan dengan tujuan untuk menambah wawasan mereka, sekaligus sebagai usaha pencegahan bagi diri siswa agar memiliki persiapan ketika suatu saat mengalami permasalahan karir.

Biblio-therapy diartikan sebagai suatu bentuk layanan terapi melalui disediakannya buku yang menunjang karir untuk memotivasi karir siswa. Buku-buku yang bertemakan dunia kerja, seperti persiapan mental menuju dunia kerja, langkah-langkah menentukan usaha kerja, tips membuat lamaran, mempersiapkan aset usaha. Keuntungan dari keterlibatan Biblio-therapy adalah bisa dipakai untuk merangsang siswa dalam berpikir dan menganalisa sikap dalam menentukan perencanaan karir.

Berdasarkan fenomena yang ditemukan dilapangan ada sebagian siswa kebingungan dalam merencanakan karir, dihadapkan dengan sejumlah pilihan dan permasalahan tentang rencana karir yang mereka akan pilih nantinya. Perencanaan karir yang matang saat sekolah bisa membantu siswa untuk lebih mengenal dan memahami potensi dan bakat yang dimiliki oleh setiap siswa termasuk disekolah. Perencanaan karir yang dimiliki oleh siswa berguna untuk studi lanjut, dan pemilihan pekerjaan. Dengan meningkatnya perencanaan karir siswa maka tingkat pengangguran diKalimantan Barat dapat dikurangi.

Ketidaksiapan siswa dalam memasuki dunia kerja juga terjadi pada siswa Sekolah Menengah Atas Negeri 1 Bengkayang. Hal ini ditunjukan dengan gejala-gejala yang ditemukan pada saat observasi pada siswa kelas XI IPS. Adapun kejala yang muncul antusias membahas mengenai studi lanjut atau pekerjaan, bingung menentukan cita-citanya setelah lulus sekolah dan bahkan ada pula yang mengatakan tidak tahu pilihan kerja kedepan, hal ini disebabkan kurangnya informasi mengenai perencanaan karir baik yang berkaitan dengan studi lanjut, pemilihan rencana pekerjaan, serta kurangnya minat siswa melanjutkan keperguruan tinggi. Mereka hanya mengandalkan keterampilan seadanya dengan pengetahuan tentang dunia kerja yang minim. Selain itu, pemberian layanan bimbingan dan konseling yang diterima siswa belum optimal di Sekolah Menengah Atas Negeri 1 Bengkayang tersebut.

Berdasarkan kenyataan diatas, maka peneliti tertarik untuk melakukan penelitian dengan judul "Meningkatkan Perencanaan Karir Melalui Layanan Informasi dengan Teknik Biblio-therapy Pada Siswa Kelas XI IPS 2 Sekolah Menengah Atas Negeri 1 Bengkayang".

\section{METODE PENELITIAN}

Penelitian ini menggunakan Metode penelitian tindakan. Suharsimi Arikunto (2010: 4) mengatakan bahwa: "Penelitian tindakan merupakan suatu pencerminan terhadap kegiatan pembelajaran berupa sebuah tindakan yang sengaja dimunculkan dan terjadi dalam sebuah kelas secara bersamaan". Dede Rahmat Hidayat dan Aip Badrujaman (2011:18) "prosedur 
penelitian tindakan bimbingan dan konseling terdapat 4 tahapan yang lazim dilalui yaitu: (1) Perencanaan (2) pelaksanaan (3) pengamatan (4) Reflksi."

Penelitian ini dilakukan di Sekolah Menengah Atas Negeri 1 Bengkayang yaitu dilaksanakan pada tanggal 25 April 2019 sampai dengan 17 Mei 2019 pelaksanaan dilakukan pada semester II tahun pelajaran 2018/2019 dengan subjek penelitian 34 orang siswa. Teknik pengumpul datanya menggunakan teknik observasi langsung, teknik komunikasi langsung, teknik komunikasi tidak langsung, dan teknik studi dokumenter. Sedangkan alat pengumpul datanya menggunakan pedoman observasi, panduan wawancara, skala psikologis yang selanjutnya dilakukan trigulasi data untuk menggali kebenaran informasi melalui sumber perolehan data yang berbeda, dan dokumentasi.

Teknik analisis data dalam penelitian ini menggunakan analisis data kuantitaif dan kualitati dengan langkah-langkahnya berupa pengumpulan dan penafsiran data serta penyimpulan hasil perolehan data penelitian.

\section{HASIL}

Hasil perhitungan berdasarkan tolok ukur perhitungan yang telah ditentukan. Berdasarkan penyebaran skala psikologis sebelum dilakukan tindakan peneliti terhadap 34 siswa kelas XI IPS 2 Sekolah Menengah Atas Negeri 1 Bengkayang menunjukan bahwa aspek mempelajari informasi karir 52\%, aspek membicarakan karir dengan orang dewasa $53 \%$, aspek mengetahui persyaratan pendidikan untuk pekerjaan yang diinginkan $49 \%$, aspek Dapat merencanakan apa yang harus dilakukan setelah tamat sekolah $48 \%$. Dari keempat aspek itu semua masuk dalam kategori "Cukup". Untuk mempermudah melihat secara perencanaan karir siswa Sekolah Menengah Atas Negeri 1 Bengkayang, dapat disajikan dalam bentuk tabel 4.2 sebagai berikut:

Tabel 4.2

Hasil Skala Psikologis Perencanaan KarirSiswa Sebelum Tindakan

\begin{tabular}{clcccc}
\hline No & \multicolumn{1}{c}{ Aspek Variabel } & $\begin{array}{c}\text { Skor } \\
\text { Aktual }\end{array}$ & $\begin{array}{c}\text { Skor } \\
\text { Ideal }\end{array}$ & \% & Kategori \\
1 & $\begin{array}{l}\text { Mempelajari Informasi karir } \\
2\end{array}$ & 577 & 1122 & $52 \%$ & Cukup \\
& $\begin{array}{l}\text { Membicarakan karir dengan orang } \\
\text { dewasa }\end{array}$ & 595 & 1122 & $53 \%$ & Cukup \\
\hline $\begin{array}{l}\text { Mengetahui persyaratan } \\
\text { pendidikan untuk pekerjaan yang } \\
\text { diinginkan }\end{array}$ & 497 & 1020 & $49 \%$ & Cukup \\
$\begin{array}{l}\text { Dapat merencanakan apa yang } \\
\text { harus dilakukan setelah tamat } \\
\text { sekolah }\end{array}$ & 399 & 816 & $48 \%$ & Cukup \\
Jumlah Persentase Keseluruhan & $\mathbf{2 0 6 8}$ & $\mathbf{4 0 8 0}$ & $\mathbf{5 1 \%}$ & Cukup \\
\hline
\end{tabular}

Berdasarkan tabel di atas dapat di jelaskan sebagai berikut:

1. Aspek mempelajari informasi karir, mendapatkan perolehan skor aktual 577 dari skor ideal 1122 dengan presentase 52\% dalam kategori "cukup". Demikian dapat dijelaskan bahwa siswa kelas XI IPS 2 Sekolah Menengah Atas Negeri 1 Bengkayang, dengan mempelajari informasi karir agar individu memiliki pengetahuan (informasi), lingkungan perguruan tinggi, serta sumber-sumber belajar termasuk buku maupun internet. Informasi yang diperoleh sangat diperlukan agar individu lebih mudah dalam perencanaan dan mengambil keputusan. Namun kenyataannnya siswa tidak berusaha menggali dan mencari informasi karir, siswa tidak berusaha mengumpul kan informasi karir dan mempelajari informasi-informasi tentang perencanaan karir.

2. Aspek membicarakan karir dengan orang dewasa, mendapatkan perolehan skor aktual 595 dari skor ideal 1122 dengan presentase 53\% dalam kategori "cukup". Demikian dapat 
dijelaskan bahwa siswa kelas XI IPS 2 Sekolah Menengah Atas Negeri 1 Bengkayang, siswa kurang atau tidak berusaha mengambil keputusan karir dengan orang tua bahkan siswa kurang berani bertanya dari berbagai sumber (guru, orang tua, orang yang sukses dan sebagainya).

3. Aspek mengetahui persyaratan pendidikan untuk pekerjaan yang diinginkan, mendapatkan perolehan skor aktual 497 dari skor ideal 1020 dengan presentase $49 \%$ dalam kategori "Cukup". Demikian dapat di jelaskan bahwa siswa kelas XI IPS 2 Sekolah Menengah Atas Negeri 1 Bengkayang, masih ada siswa yang belum berusaha mencari informasi tentang pekerjaan soal awal mula perjalanan karir, dan siswa belum tertarik mengetahui persyaratan-persyaratan pekerjaan yang akan mereka pilih.

4. Aspek dapat merencanakan apa yang harus dilakukan setelah tamat sekolah, mendapatkan perolehan skor aktual 399 dari skor ideal 816 dengan presentase $48 \%$ dalam kategori "Cukup". Dilihat dari hasil pengisian skala psikologis dapat dijelaskan bahwa siswa kelas XI IPS 2 Sekolah Menengah Atas Negeri 1 Bengkayang, belum ada terdapat rencana dan ketidak siapan siswa setelah tamat sekolah. Kemampuan siswa dalam mempersiap kan karirnya masih rendah baik dengan studi lanjutan, dan pemilihan rencana pekerjaan. Bahkan mereka masih kebingungan, tidak memiliki arah dan jawaban yang pasti.

Berdasarkan penjelasan di atas, dapat digambarkan sebagaimana yang tertera dalam diagram 4.1 sebagai berikut:

Grafik 4.1

Persentase Aspek Perencanaan Karir Siswa Sebelum Tindakan

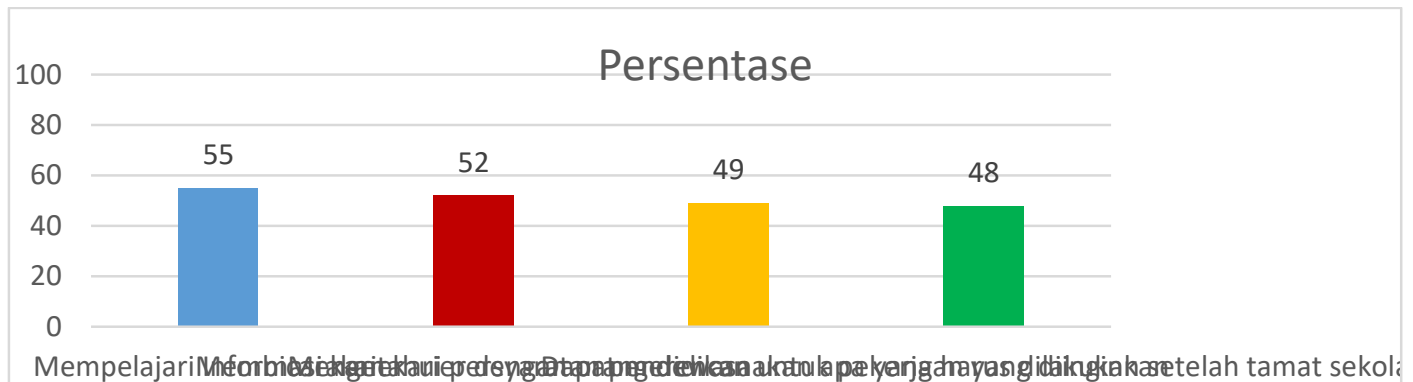

Berdasarkan diagram di atas, dapat di ketahui bahwa perencanaan karir pada subyek penelitian sebelum dilaksanakan layanan informasi dengan teknik Biblio-therapy pada siswa kelas XI IPS 2 Sekolah Menengah Atas Negeri 1 Bengkayang tergolong dalam kategori "cukup", dengan presentase keseluruhan 51\%. Hal ini terlihat dari hasil skala psikologis yang telah di isi oleh siswa sebelum dilaksanakannya layanan informasi dengan teknik Bibliotherapy, terdapat empat aspek yang berada dalam kategori "cukup". Oleh karena itu peneliti memberikan layanan informasi dengan teknik Biblio-therapy dengan harapan dapat meningkatkan perencanaan karir pada siswa.

\section{Siklus I}

1. Perencanaan (Plan)

Perencanaan siklus dilaksanakan untuk menyusun Rencana Pemberian Layanan (RPL). Sebelum membuat perencanaan, peneliti dan guru bimbingan dan konseling berdiskusi mengenai minat melanjutkan ke perguruan tinggi pada siswa melalui layanan informasi dengan teknik Biblio-therapy. Dalam layanan informasi ini dapat membantu siswa dalam memilih perguruan tinggi yang mereka minati, siswa tidak hanya asal pilih perguruan tinggi namun mereka juga perlu mengenali perguruan tinggi yang akan mereka pilih. 
Peneliti mempersiapkan materi yang akan disampaikan serta pedoman observasi yang akan digunakan dalam mengamati proses kegiatan yang akan dilaksanakan.

2. Pelaksanaan (Action)

Tindakan siklus I dilaksanakan pada hari Selasa 7 Mei 2019 dan hari kamis 9 Mei 2019. Sedangkan yang melaksanakan tindakan adalah peneliti, guru bimbingan dan konseling bertindak sebagai observer. Adapun pemberian tindakan pada siklus I dapat diuraikan sebagai berikut:

a. Pertemuan Pertama

Pertemuan pertama dilakukan pada hari Selasa tanggal 7 Mei 2019 dengan topik Memahami informasi karir sesuai bakat dan minat. guru bimbingan dan konseling bertindak sebagai kolaborator. lamanya pertemuan 60 menit. Pada pertemuan pertama yaitu berupa pemberian layanan informasi dengan teknik Biblio-therapy, pada layanan informasi tersebut terdiri dari 3 tahap yaitu :

1) Kegiatan awal, peneliti memimpin do'a, menanyakan kabar, perkenalan dan Ice Braking agar siswa tidak terlalu tegang. Pada pertemuan ini siswa masih belum aktif dan masih malu dalam mengikuti kegiatan.

2) Kegiatan inti, peneliti memberikan penjelasan mengenai materi yang di bahas, menjelaskan poin-poin dari materi bahasan tersebut, memberikan pertanyaan kepada siswa, melibatkan siswa dalam memberikan layanan dengan meminta siswa mengemukakan pendapat tentang materi, memberikan kesempatan kepada siswa untuk bertanya dan berdiskusi, melakukan refleksi dari hasil kegiatan, berkaitan dengan perencanaan karir. Dengan demikian kegiatan yang dilakukan belum berjalan sesuai harapan.

3) Kegiatan akhir, peneliti menyimpulkan hasil kegiatan, menanyakan kembali kepada siswa tentang materi yang sudah disampaikan, mengevaluasi hasil dari penjelasan materi yang sudah disampaikan.

b. Pertemuan Kedua

Pertemuan kedua dilakukan pada hari kamis 9 Mei 2019 dengan topik Peran lingkungan keluarga terhadap perencanaan karir.

1) Kegiatan awal, peneliti memimpin do'a, mengabsen siswa, menanyakan kabar. Pada pertemuan ini siswa masih sudah mulai aktif serta mulai berani mengemukakan pendapatnya.

2) Kegiatan inti, siswa sudah mulai melakukan diskusi terkait pembahasan topik, siswa mulai ikut dalam mengemukan pendapat dan terlihat aktif melibatkan diri dalam kegiatan tersebut. Dalam pertemuan ini peneliti menggunakan teknik Biblio-therapy yaitu dengan menggunakan tayangan Slide Power point dan buku karir serta video, "Tips Perencanaan Karir". Namun masih terdapat beberapa siswa yang masih kurang percaya diri, masih malu bertanya.

3) Kegiatan akhir, peneliti menyimpulkan hasil kegiatan, menanyakan kembali kepada siswa tentang materi yang sudah disampaikan, mengevaluasi hasil dari penjelasan materi yang sudah disampaikan.

3. Pengamatan (Observer)

Pengamatan dilakukan setelah dua kali pertemuan. Kegiatan observasi dalam kegiatan ini dilakukan oleh kolaborator yaitu guru bimbingan dan konseling. Kolaborator melakukan observasi selama proses layanan informasi dengan teknik Biblio-therapy berlangsung guna mengetahui sejauh mana peneliti dan siswa terlibat dalam kegiatan yang dilaksanakan.

Berdasarkan hasil pengamatan observasi dalam layanan informasi dengan teknik Biblio-therapy pada siklus I pertemuan kedua ini memperoleh hasil yang masih kurang memuaskan. Terdapat beberapa indikator yang belum terlaksana dengan baik. Masih terdapat siswa yang malu-malu dalam bertanya, dan kurang percaya diri, dan masih berada dalam kategori "cukup".

Terdapat kelemahan-kelemahan yang ditunjukan siswa seperti: masih ada siswa yang belum begitu aktif terlibat dalam kegiatan, malu-malu saat bertanya, kurang percaya diri, hal itu juga dikarenakan kurang optimalnya peneliti dalam menyampaikan materi 
dikelas, seperti mebina hubungan baik dengan siswa juga belum tampak dilakukann, serta tidak adanya teguran untuk siswa yang tidak semangat belajar di kelas. Dengan demikian akan di lanjutkan pada siklus selanjutnya, sehingga sampai pada hasil yang diharapkan.

4. Refleksi

Setelah tindakan siklus I dilaksanakan, peneliti kembali menyebar skala psikologis kepada subjek penelitian, penyebaran skala psikologis dilakukan setelah tindakan siklus I selesai dilaksanankan. Hal ini dilakukan untuk mengetahui sejauh mana peningkatan perencanaan karir siswa setelah diberikan layanan informasi dengan teknik Biblio-therapy pada siklus I.

Berdasarkan dari hasil penyebaran skala psikologis dan panduan observasi kegiatan layanan informasi dengan teknik Biblio-therapy yang telah di sesuaikan dengan kolaborator bahwa akan ada perbaikan siklus selanjutnya dengan memberikan tindakan siklus ke II, sehingga sampai pada hasil yang diharapkan hal ini ditunjukan dengan angka persentase $64 \%$ dari $51 \%$ sebelum diberikan tindakan.

\section{Siklus II}

1. Perencanaan (Plan)

Sebelum melaksanakan tindakan pada siklus II terlebih dahulu peneliti membuat perencanaan tindakan. Pada tahap perencanaan ini peneliti berdiskusi dengan guru bimbingan dan konseling di Sekolah Menengah Atas Negeri 1 Bengkayang. Peneliti dan guru bimbingan dan konseling mempersiapkan materi yang akan disampaikan serta pedoman observasi yang akan digunakan dalam mengamati proses kegiatan yang akan dilaksanakan serta menggunakan teknik yang tepat yaitu teknik Biblio-therapy guna untuk meningkatkan perencanaan karir siswa.

2. Pelaksanaan (Action)

Pelaksanan layanan informasi dengan teknik Biblio-therapy pada siklus II dilakukan melalui 2 kali pertemuan yaitu pada hari Jumat, 10 Mei 2019 dan Senin,13 Mei 2019. Yang melaksanakan tindakan adalah peneliti, guru bimbingan dan konseling sebagai observer. Adapun pelaksanaan tindakan yang dilakukan pada siklus II dapat diuraikan sebagai berikut:

a. Pertemuan Pertama

Perencanaan siklus dilaksanakan pada Jumat, 10 Mei 2019 dengan topik Melanjutkan perguruan tinggi, alokasi waktu 60 menit. Dalam layanan informasi ini diharapkan dapat membantu siswa dalam mengatasi permasalahannya. Adapun tahapan dalam layanan informasi dengan teknik Biblio-therapy yaitu:

1) Kegiatan awal, peneliti membuka pertemuan dengan mengucapkan salam, do'a, kemudian mengabsensi siswa dan semua siswa hadir. Setelah itu peneliti mulai memberikan gambaran umum berkaitan dengan kegiatan yang akan dilaksanakan hari ini, pada tahap ini peneliti dan siswa sudah mulai akrab dan suasana kegiatan juga tidak terlalu tegang.

2) Kegiatan inti, terlihat beberapa siswa siap mengikuti kegiatan. Peneliti membahas topik berdasarkan Rencana Pelaksanaan Layanan (RPL). Kemudian siswa saling terlibat dalam diskusi terkait topik yang akan dibahas. Terlihat beberapa siswa sudah mulai aktif, beberapa siswa sudah mulai memperahatikan, dan sudah ada kesediaan untuk mendengar dan bertanya tentang perencanaan karir, tetapi belum sepenuhnya, masih terdapat beberapa siswa yang belum aktif dan masih malu-malu. Dalam pertemuan ini peneliti masih menggunakan teknik Biblio-therapy dengan menetapkan yaitu dengan menggunakan tayangan video yaitu "Tips memilih prodi kuliah".

3) Kegiatan akhir, peneliti menyimpulkan hasil kegiatan, menanyakan kembali kepada siswa tentang materi yang sudah disampaikan, mengevaluasi hasil dari penjelasan materi yang sudah disampaikan.

\section{b. Pertemuan Kedua}


Perencanaan siklus dilaksanakan pada Senin, 13 Mei 2019 dengan topik Sukses memasuki dunia kerja, alokasi waktu 45 menit. Dalam layanan informasi ini diharapkan dapat membantu siswa dalam mengatasi permasalahannya. Adapun tahapan dalam layanan informasi dengan teknik Biblio-therapy yaitu:

1) Kegiatan awal, peneliti membuka pertemuan dengan mengucapkan salam, do'a, kemudian mengabsensi siswa dan semua siswa hadir. Setelah itu peneliti mulai memberikan gambaran umum tentang kegiatan yang akan dilaksanakan hari ini, pada tahap ini peneliti dan siswa sudah mulai akrab dan suasana kegiatan pun tidak terlalu tegang.

2) Kegiatan inti, terlihat beberapa siswa siap mengikuti kegiatan. Peneliti membahas topik berdasarkan Rencana Pemberian Layanan (RPL). Kemudian siswa saling terlibat dalam diskusi terkait topik yang akan dibahas. Terlihat beberapa siswa sudah mulai aktif, beberapa siswa sudah mulai memperahatikan, dan sudah ada kesediaan untuk mendengar dan bertanya tentang perencanaan karir,. Dalam pertemuan kedua peneliti masih menggunakan teknik Biblio-Therapay dengan menggunakan tayangan video yaitu "50 PTN-PTS Terbaik".

3) Kegiatan akhir, peneliti menyimpulkan hasil kegiatan, menanyakan kembali kepada siswa tentang materi yang sudah disampaikan, mengevaluasi hasil dari penjelasan materi yang sudah disampaikan dan terakhir salam penutup dan berdoa.

3. Pengamatan (observer)

Pengamatan dilakukan setelah dua kali pertemuan. Kegiatan observasi dalam kegiatan ini dilakukan oleh kolaborator yaitu guru bimbingan dan konseling. Kolaborator melakukan observasi selama proses layanan informasi dengan teknik Biblio-therapy berlangsung guna mengetahui sejauh mana peneliti dan siswa terlibat dalam kegiatan yang dilaksanakan. Berdasarkan observasi dalam kegiatan layanan informasi dengan teknik Biblio-therapy dari tabl diatas dapat disimpulkan pelaksanaan layanan informasi dengan teknik Biblio-therapy sudah sepenuhnya berjalan dengan baik. Yaitu siswa dan peneliti sudah bisa membina hubungan dengan baik dalam proses pemberian layanan, siswa sudah banyak aktif bertanya dan terlibat dalam poses pelaksanaan layanan dan sudah mempunyai gambaran untuk karir yang akan mereka pilih.

4. Refleksi

Setelah dilaksanakan tindakan penelitian siklus II peneliti kembali menyebarkan skala psikologis untuk mengetahui apakah perencanaan karir siswa meningkat sesuai dengan harapan peneliti setelah diberikan layanan informasi dengan teknik Biblio-therapy. Dari hasil skala psikologis perencanaan karir siswa. Berdasakan dari hasil penyebaran skala psikologis dan panduan observasi kegiatan layanan informasi sesuai dengan teknik Biblio-therapy yang telah didiskusikan dengan kolaborator bahwa pelaksanaan layanan tindakan siklus II telah terjadi peningkatan perencanaan karir dengan mencapai persentase $74 \%$ dengan kategori "Baik" dengan peresentase keseluruhan aspek meningkat dari $64 \%$ menjadi $74 \%$ peningkatan tersebut sebesar $10 \%$. maka proses penelitian pun dihentikan karena sudah mencapai indikator keberhasilan yang diharapkan.

Berdasarkan hasil tindakan dan sebaran skala psikologis pada siklus I dan

II terhadap meningkatkan perencanaan karir terdapat peningkatan yang signifikan dari hasil peresentase hasil penelitian sebelum tindakan $51 \%$ kemudian meningkat menjadi $64 \%$ pada siklus pertama pertemuan kedua dan kembali meningkat menjadi $74 \%$ pada siklus ke II pada pertemuan kedua dengan kategori "Baik". Presentase skala psikologis meningkatkan perencanaan karir dapat dilihat pada diagram 4.4 di bawah ini: 


\section{Diagram 4.4 \\ Peresentase Skala Psikologis Perencanaan Karir Siswa Sebelum Dan Sesudah PelaksanaanTindakan Siklus I Dan II}

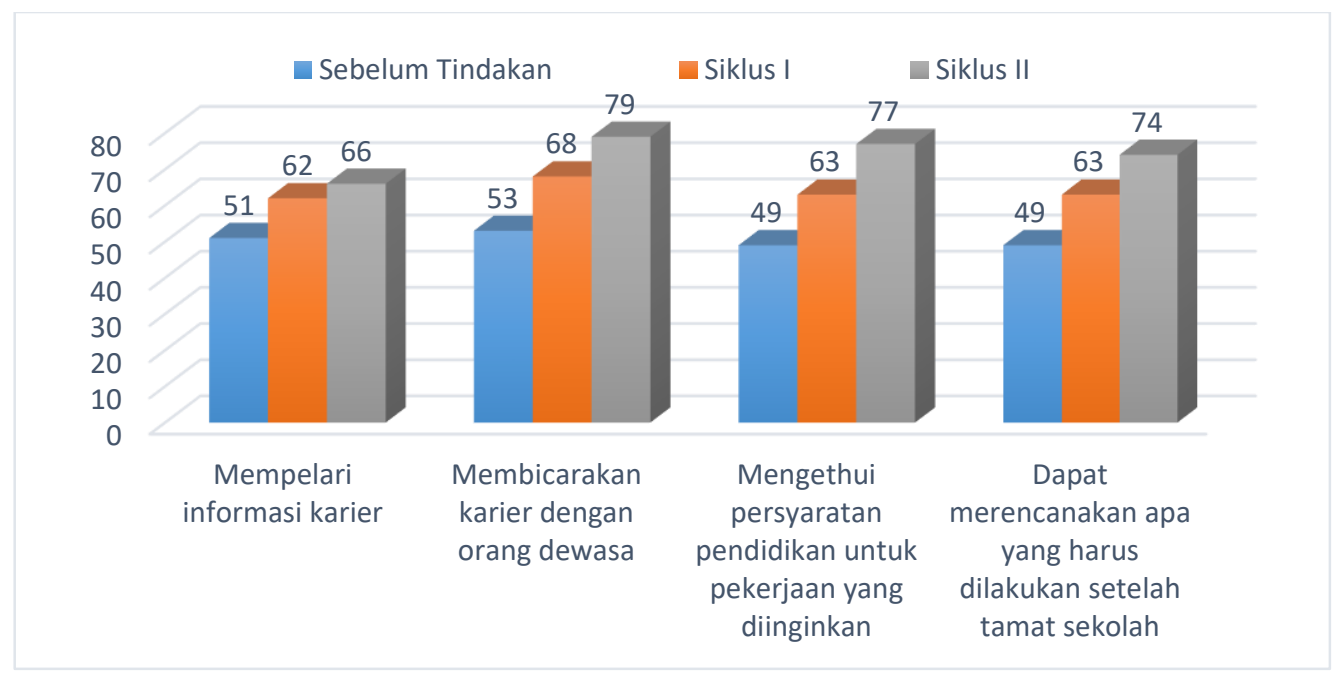

Berdasarkan diagram diatas, terlihat perbandingan perencanaan karir siswa sebelum tindakan dan sesudah dilakukannya tindakan baik di siklus I maupun di siklus II terus mengalami peningkatan di setiap aspeknya.

\section{PEMBAHASAN}

Berdasarkan dari hasil pelaksanaan siklus I dan II, diperoleh kesimpulan secara umum bahwa melalui pelaksanaan layanan informasi dengan teknik Biblio-therapy dapat meningkatkan perencanaan karir siswa. Hal ini dapat dilihat dari analisis skala psikologis sebelum di berikan tindakan dengan presentase 51\% dengan kategori "Cukup", dapat di interpretasikan bahwa siswa kelas XI IPS 2 Sekolah Menengah Atas Negeri 1 Bengkayang masih ada rasa keterpaksaan, tidak bersemangat dan tidak berusaha untuk merencanakan karir, belum ada niat untuk merencanakan karir, belum bisa menaruh perhatian yang besar dan belum bisa berkonsentrasi dalam memilih karir, belum bersungguh-sungguh dalam menentukan cita-cita dan menggambil keputusan karirnya. Pada siklus I mengalami peningkatan setelah dilaksanakan tindakan menjadi 64\% dengan kategori "Cukup", dan dapat di interpretasikan bahwa siswa kelas XI IPS 2 Sekolah Menengah Atas Negeri 1 Bengkayang, masih terdapat beberapa orang yang belum aktif bertanya, masih terdapat siswa yang belum mampu merespon dan memberikan reaksi terhadap apa yang di sampaikan, masih terdapat siswa yang belum bisa fokus pada saat peneliti menjelaskan, masih terdapat beberapa siswa yang selalu terlihat malu mengemukakan pendapat di depan umum. Dan pada siklus II setelah dilaksanakan tindakan meningkat sesuai dengan harapan peneliti dengan persentase keseluruhan menjadi $74 \%$ dengan kategori baik dan dapat di interpretasikan bahwa siswa kelas XI IPS 2 Sekolah Menengah Atas Negeri 1 Bengkayang, sudah tidak malu-malu saat berbicara dan bertanya, sudah tertarik dan mampu merespon apa yang di sampaikan peneliti, bersemangat, fokus pada saat peneliti menjelaskan materi dan berani menjawab saat diberikan pertanyaan, sudah adanya rasa ingin tahu dan mudah di ajak bekerja sama.

Penerapan layanan informasi dengan teknik Biblio-therapy sudah dilaksanakan dengan maksimal, meskipun pada awal pertemuan terdapat kendala, yaitu terdapat beberapa siswa masih malu untuk berbicara, masih kurang aktif dalam diskusi, belum tertarik dan belum fokus pada apa yang peneliti sampaikan. Terlihat pada hasil observasi yang dilakukan oleh guru bimbingan dan konseling pada siklus I pertemuan pertama dan kedua bahwa pada tahap persiapan peneliti belum bisa menjalin keakraban kepada siswa, serta beberapa siswa belum begitu telibat dengan aktif pada saat proses pelaksanaan kegiatan pemberian layanan 
informasi. Akan tetapi sebisa mungkin peneliti berusaha agar kendala tersebut bisa diatasi terbukti dengan siklus II peneliti sudah bisa mengatasi dengan adanya perubahan pada diri siswa di kelas.

E. Amundson, Joan Harris-Bowlsbey, Spencer G. Niles (Terjemahan Helly Prajitno Soetjipto, Sri Mulyantini Soetjipto, 2016:216) Buku bisa memungkinkan klien untuk memiliki insight tentang dirinya yang mungkin belum dikenali. Biblio-therapy digunakan untuk menstimulasi diskusi tentang berbagai masalah, mengkomunikasikan nilai-nilai dan sikapsikap baru dan menyediakan solusi-solusi realistis untuk berbagai masalah.

Berdasarkan beberapa pendapat di atas, dapat disimpul kan bahwa teknik Biblio-therapy adalah mendeskripsikan penggunaan buku-buku sebagai bahan untuk menemukan apa yang akan menjadi objek sesuatu yang pilih, misal dengan membaca kita mendaptkan pengetahuan, yang sesuai dengan bakat dan minat yang kita miliki sehingga kita mendapatkan pemikiran, dan sikap untuk lebih positif setelah proses membaca buku.

Layanan informasi dengan teknik Biblio-thrapy memiliki manfaat besar bagi individu dalam meningkatkan perencanaan karir siswa, seperti dapat memberikan pengalaman belajar yang bisa diterapkan oleh individu, membekali individu dengan berbagai macam pengetahuan tentang lingkungan yang diperlukan untuk memecahkan masalah yang di hadapi berkaitan dengan pendidikan, pekerjaan memungkinkan individu dapat menentukan arah hidup untuk memilih karir sesuai dengan bakat dan minatnya kemana, dengan cara memberikan informasi seputar karir. Berdasarkan hasil observasi layanan informasi dengan teknik Biblio-therapy pada siklus I dan II terdapat peningkatan perencanaan karir siswa.

Sebagai mana telah di jelaskan diatas bahwa layanan informasi dengan teknik Bibliotherapy dapat meningkatkan perencanaan karir siswa kelas XI IPS 2 SMA Negeri 1 Bengkayang. Dapat di lihat dari hasil peresentase hasil penelitian sebelum tindakan $51 \%$ kemudian meningkat menjadi $64 \%$ pada siklus pertama pertemuan kedua dan kembali meningkat menjadi $74 \%$ pada siklus ke II pada pertemuan kedua dengan kategori "Baik".

\section{SIMPULAN}

Berdasarkan hasil pengolahan data, secara umum dapat disimpulkan bahwa meningkatkan perencanaan karir melalui layanan informasi dengan teknik Biblio-Therapy pada siswa kelas XI IPS 2 Sekolah Menengah Atas Negeri 1 Bengkayang dengan kategori "Baik". Secara khusus kesimpilan perencanaan karir antara lain :Gambaran perencanaan karir siswa kelas XI IPS 2 Sekolah Menengah Atas Negeri 1 Bengkayang sebelum dilaksanakannya layanan informasi dengan teknik Biblio-Therapy kategori "cukup", hal ini dapat dilihat dari analisis sebelum diberikan tindakan dengan kategori "cukup" dan kurang dapat di interpretasikan bahwa siswa kelas XI IPS 2 Sekolah Menengah atas Negeri 1 Bengkayang masih ada rasa keterpaksaan, tidak bersemangat dan kemampuan siswa dalam mempersiapakan kariernya masih rendah baik berkaitan dengan studi lanjutan, pemilihan rencana pekerjaan maupun berkaitan dengan ketidaksiapan para lulusan Sekolah Menengah Atas dalam memasuki pendidikan lanjutan atau dunia kerja, belum bisa menaruh perhatian yang besar dan belum bisa berkonsentrasi dalam memilih karier yang diinginkan.Pelaksanaan layanan informasi dengan teknik Biblio-Therapy dalam meningkatkan perencanaan karier siswa kelas XI IPS 2 Sekolah Menengah Atas Negeri 1 Bengakayang, di lakukan dengan tahapan yaitu: kegiatan awal, kegiatan inti, kegiatan akhir. Pada pelaksanaan layanan informasi ini dinyatakan Baik.Terdapat peningkatan perencanaan karir siswa kelas XI IPS 2 Sekolah Menengah Atas Negeri 1 Bengkayang setelah diberikan layanan informasi dengan teknik Biblio-Therapy dengan kategori "Cukup" dan mengalami peningkatan peresentase setelah dilaksanakan tindakan siklus I tetapi masih berada pada kategori "Cukup" dan meningkat sesuai dengan harapan peneliti setelah dilaksanakan siklus II dengan Kategori "Baik" dapat di interpretasikan bahwa siswa kelas XI IPS 2 Sekolah Menengah Atas Negeri 1 Bengkayang, siswa sudah tidak malu-malu berbicara dan bertanya, sudah merespon peneliti saat menjelaskan materi dan berani menjawab saat ditanya, sudah memahami materi yang dijelaskan oleh peneliti, adanya rasa ingin tahu dan lebih bersemangat. 


\section{DAFTAR PUSTAKA}

Badan Pusat Statistik Kalimantan Barat. 2019. Angka Kelulusan dan Pengangguran Lulusan SMA.

Dede Rahmat Hidayat dan Aip Badrujama. 2012. Penlitian tindakan dalam Bimbingan dan konseling. Jakarta : PT. Indeks.

Dewa Ketut Sukardi. 2008. Pengantar Pelaksanaan Program Bimbingan dan Konseling di Sekolah. Jakarta: Rineka Cipta.

E. Amundson, Joan Harris-Bowlsbey, Spencer G. Niles (Terjemahan Helly Prajitno Soetjipto, Sri Mulyantini Soetjipto. 2016. Elemen-elemen Penting dalam Konseling Karir: Berbagai Proses dan Teknik. Yogyakarta: Pustaka Pelajar.

Prayitno. 2012. Seri Panduan Layanan Bimbingan dan Kegiatan Pendukung Konseling. Program Pendidikan Profesi Konselor: UNP.

Suharsimi Arikunto. 2010. Prosedur Penelitian Suatu Pendekatan Praktik. Jakarta : Rineka Cipta.

Uman Suherman. 2008. Konseling Karir Sepanjang Rentang Kehidupan. Bandung: Universitas Pendidikan Indonesia.

Winkel, Sri Hastuti. 2013. Bimbingan Dan Konseling di Institusi Pendidikan: Yogyakarta: Media. Abadi. 